\title{
The Praxis of School-Based Management on Curriculum and Learning in the Philippines
}

\author{
Jonathan S. Villanueva ${ }^{1}$ \& Ruth A. Ortega-Dela $\mathrm{Cruz}^{2}$ \\ ${ }^{1}$ Department of Education, Calamba City, Laguna, Philippines \\ ${ }^{2}$ Institute for Governance and Rural Development, College of Public Affairs and Development, \\ University of the Philippines Los Baños, Laguna, Philippines \\ Correspondence: Ruth A. Ortega-Dela Cruz, University of the Philippines Los Baños, Laguna, \\ Philippines. \\ Email: raortegadelacruz@up.edu.ph
}

doi: 10.23918/ijsses.v6i2p89

\begin{abstract}
Educational leaders and policy makers worldwide are always looking for reforms to make sure that academic institutions are able to produce functionally literate individuals in a decentralized educational system. School-Based Management (SBM) has served as a reform concretizing decentralization in the basic education sector in different parts of the world. This study aimed to analyse the praxis of SBM on curriculum and learning in one of the public schools in the Philippines. It employed survey research method to randomly selected students and purposively sampled English, Science and Mathematics (ENSCIMA) teachers and the school head. Results revealed different instructional practices employed by the teachers particularly in the three major subject areas identified. But despite these practices, the study suggested that educational institutions must still work on programs and projects that will fortify their partnerships and linkages in the community and other public and private institutions. This will help improve the pedagogical techniques and instructional materials so as to respond to the diverse needs of the students towards effective and efficient curriculum and learning.
\end{abstract}

Keywords: Curriculum, Learning Outcomes, Praxis, School-Based Management, Philippines

\section{Introduction}

Education leaders and policy makers are always seeking for reforms to improve the quality of basic education in their country. However, despite these initiatives of leading people towards literacy, every institution is still facing its own problems that need to be addressed. These problems, especially in the public school, encompass high dropout rate, quality educational service, high repetition rate, and limited holding capacity of the schools (Abulencia, 2012). A common structural problem that has run through education views is the centralization of education. This centralization of education poses a serious problem that makes it very challenging to provide education services in a centralized fashion. This problem has been associated to conceptual, technical, managerial, and financial demands of education systems on government capacities, especially in the developing world and the increasing complexity of education (World Bank, 2007). This has paved the way for the decentralization of organizational management.

Decentralization is a process of transferring the substantive decision making power from a higher office to the local government. It typically includes one or more of the following features: decentralized revenue generation, curriculum design, school administration, and teacher hiring and management. Decision making authority for these types of functions is devolved to regional/municipal governments or to schools themselves (Ling, Khattri, \& Jha, 2010). In the context of education, functions such as policymaking, revenue generation, curriculum design, school administration, and teacher management are commonly 
transferred to the school itself. Decentralizing management in educational institutions is a good strategy to help address the problems on governance and inefficiencies in providing the basic needs of the community and society as a whole. Likewise, this leads to a more efficient allocation of resources necessary to bring about improvements in the quality of education being provided by the schools.

Decentralization is a key feature of institutional reform throughout the world as it empowers the people in taking active role in local decision-making process. Thus, they help improve the government performance by addressing the problems connected to information and communication inefficiency by bringing decision-making closer to the people concerned. However, decentralization can also worsen the provision of public goods in the presence of externalities, lack of technical capabilities by local governments, or capture of lower-level administration by local elites (Galiani \& Schargrodsky, 2002).

Galiani and Schargrodsky (2002) mention that in order to respond to this decentralization process, SiteManagement or School-Based Management (SBM) has served as a key reform program concretizing decentralization in the basic education sector in different parts of the world. This is a policy of allowing schools autonomy in terms of decision-making (De Grauwe, 2004). Responsibility and decision-making over different types of school operations are transferred to individuals at the school level, who in turn must conform within a set of centrally determined policies. The popularity of SBM is evidenced by the large number of development agencies promoting it as a key component of the decentralization reforms and the growing number of countries that have adopted aspects of this approach (Gertler, Patrinos, \& Codina, 2006).

Upholding the need to improve the quality of education, educational institutions all over the world have been exerting so much efforts which has paved the way for the existence of School-Based Management (SBM) in which the main purpose is the improvement of educational outcomes. School-Based Management entices many education managers and experts particularly in the Philippines where educational leaders strive to yield various positive results such as increase of student participation, school attendance, retention and completion rates and more importantly, improvement of student learning outcomes. The SBM in the Philippine context is a Department of Education thrust that decentralizes the decision-making power from the Central Office to individual schools to empower and enable them to respond to their own specific problems and needs. One way to empower the schools is through the SBM grant (DepEd Order No. 45, s. 2015).

The backbone of SBM, as being implemented in the public schools in the Philippines, is divided into four essential principles such as (i) Leadership and Governance, (ii) Curriculum and Learning, (iii) Management of Resources, and (iv) Accountability and Continuous Improvement. The Leadership and Governance assures a network of leadership and governance that guides the education system to achieve its shared vision, mission and goals. This makes the education system become responsive and relevant to the context of diverse learning environments. The Curriculum and Learning highlights the curriculum learning systems anchored on the community and learners' contexts and aspirations. It must be collaboratively developed and continuously improved. The Management of Resources ensures that a clear, transparent, inclusive and responsive accountability system is in place. It is collaboratively developed by the school community that monitors performance and acts appropriately on gaps and gains. The Accountability and Continuous Improvement underscores collectively and judiciously mobilized resources and are managed with transparency, effectiveness and efficiency. 
SBM is widely supported by different policy makers and even governments around the world. One reason for this is that principals, teachers and parents are the best people to manage the resources available for education to meet the needs of the wider community. In addition, its ultimate goal towards improved educational efficiency and effectiveness by increasing school autonomy and community participation is taken into account (Di Gropello, 2006). Furthermore, the first reason for the effectiveness and efficiency of SBM is that information or knowledge is within the reach of the schools. With this, the schools could use it for their benefit and it speaks distinctly of accountability of the academic communities for their decisions and actions. Most importantly, Caldwell (2004) states that the main purpose for SBM is the improvement of educational outcomes. A student outcome serves as the key measure of school performance (Dimmock, 2013).

To further illuminate the relevance of SBM, this study aimed to analyse the praxis of school-based management on curriculum and learning in the Philippines. It specifically (i) determined the instructional practices of the school in the area of English, Science and Mathematics (ENSCIMA) subjects to support curriculum and learning; (ii) described how the school supports curriculum and learning; and (iii) discussed the implication of the study towards improving the curriculum and learning component of the SBM system.

\section{Materials and Methods}

This section discusses the research methodology which includes the research design, subjects of the study, instrumentation, as well as the tools used for data analysis.

\subsection{Research Design}

The study used descriptive research design using survey methods to gather the data needed for the study. It employed self-administered survey-questionnaire, which was adopted and slightly modified for the purpose of the study. Modified instrument was validated by three experts in the field. It was pilot-tested to 10 junior students who were not part of the study.

\subsection{Subject of the Study}

The subjects of the study were composed of total enumeration of one school head and eight teachers: three English, two Science, and three Mathematics. They were purposively chosen for the study. Likewise, from a population of 294 Junior High School completers, 169 students were randomly selected with proportional allocation of the respondents. This was done to give each student an equal chance of being chosen for the study.

\subsection{Instrumentation}

The first and second sets of self-administered with four-point rating scale questionnaire were composed of 38 items. Each item determined the instructional practices used in English, Science, and Mathematics subjects under curriculum and learning component of School-Based Management system. This was administered to all the respondents. Some of the items incorporated in the survey-questionnaires were adopted from Instructional Practices Survey developed by Middle Level Leadership Centre, University of 
Missouri in 1986. The third set of the survey questionnaire was comprised of 20 items. It was used as a standard assessment tool on Awards and Incentives for Service Excellence (PRAISE) of the Philippine Department of Education. It was used to describe how the school supports curriculum and learning as assessed by the school head.

\subsection{Tools for Data Analysis}

Descriptive statistics such as frequencies, means and percentages was used to analyse the data gathered for the study.The simple mean was interpreted using the following four-point rating scale: 3.50-4.00Highly Observed; 2.50-3.49- Observed;1.50-2.49- Moderately Observed; and 1.00-1.49- Not Observed.

\section{Results and Discussion}

This section presents the major findings of the study.

\subsection{Profile of the Subjects of the Study}

Majority or five out of nine teacher respondents ranked Teacher I. Four of them belong to the age bracket 31-40. Two were in age brackets 21-30, another two in 41-50, and only one in the age bracket 51-60. In terms of student respondents, majority of them (55 per cent) were comprised of males while 45 per cent were females. According to age bracket, the highest number of the respondents or 84 per cent were in the age bracket of 16-17 years old. This is followed by 18 per cent who belong to age bracket 14-15 years and five per cent in age bracket of 18-19 years old.

When it comes to the academic performance of student respondents in ENSCIMA subjects, majority or 68 per cent of the students have achieved a "Fairly Satisfactory" academic performance or their weighted average grades fall in between 75 to 79 per cent. This indicates that most of them are still in developing stage though they are already going to enter the senior high school.

\subsection{Instructional Practices Observed in Each Subject Area}

Table 1 shows the mean of the overall assessment of student and teacher respondents in the instructional practices observed in English subject to support curriculum and learning component using school-based management system. The overall score obtained is 3.09 which indicates that all the indicators were 'Observed' as assessed by the student and teacher respondents. Based on the weighted mean, indicators 1 and 2 were 'Highly Observed' instructional practices in English subject that supported the implementation of curriculum and learning component: Discuss with my students the importance of courtesy and respect and consciously model for my students the types of personal behaviours that promote responsibility and social development among early adolescents (3.62) and Select instructional materials based upon my knowledge of my students' developmental needs and learning styles (3.54).

However, both student and teacher respondents perceived that indicators 8, 9, and 10: Select and/or adapt instructional materials to implement the prescribed curriculum (2.46); Inform (via text, call, email, or home visitation) parent/guardian as to the positive growth in student behaviour or academic performance 
(2.38); and Bring students outside the school and utilize community as an avenue for experiential learning (2.32) were 'Moderately Observed.'

Table 1: Instructional Practices Observed in English to Support Curriculum and Learning Component

\begin{tabular}{|c|c|c|}
\hline \multirow{2}{*}{ Indicators } & \multicolumn{2}{|c|}{$\begin{array}{c}\text { Weighted } \\
\text { Mean }\end{array}$} \\
\hline & $\bar{X}$ & VI \\
\hline
\end{tabular}

1 Discuss with the students the importance of courtesy and consciously model for the students the types of personal behaviours that promote responsibility and social development among early adolescents.

2 Select instructional materials based upon the knowledge of my students' developmental needs and learning styles.

3 Consider how to build up upon the students' existing knowledge and experiences.

4 Select content that meets the curriculum, competencies, and/or performance standards.

$$
\mathrm{O}
$$

5 Involve students in the process of deciding what the students will study to accomplish the curricular goals.

6 Hold card issuance and parent-teacher conference or meeting every quarter.

$7 \quad$ Visit nearby schools for benchmarking of best teaching practices and strategic instructional materials.

8 Select and/or adapt instructional materials to implement the prescribed curriculum.

9 Inform (via text, call, email, or home visitation) parent/guardian as to the positive growth in student behaviour or academic

$$
\text { performance. }
$$

10 Bring students outside the school and utilize community as an avenue for experiential learning.

The findings that English teachers were good in terms of selecting suitable instructional materials for the learners' ability and needs and in matters relative to the development of values that the students must 
exemplify inside and outside the school premises. However, as the findings revealed, their instructional practices seemed to lack linkages between school and community as partners in the success of educative process.

In addition to this, there was poor communication with the parents with regard to the students' academic progress because the three (3) English teacher respondents were not all advisers. This means that they were not required to directly inform the parents about their children's performance. They reported the matters to the respective advisers of the students and the advisers were the ones who inform the parents through text or home visitation.

This can be a contributory factor why majority of the students in English class has only achieved 75 per cent to 79 per cent or "Fairly Satisfactory" academic performance. To better the learning outcomes in English, students must be given a maximum opportunity to a variety of learning materials that are tailored to their needs, abilities, and interests. Likewise, their parents must be well-informed as to their academic performance and behaviour in class so that proper parental guidance and support can be given to them at home. It is also equally important that English teachers must expose their students to authentic learning or experiential learning through the utilization of the community as an avenue for learning. Yet, it is noteworthy to remember that a participatory school environment identifies certain attributes of school which seem to correlate positively with enhanced learning outcomes according to Brown (1990 cited in Dimmock, 2013). This suggests that all teachers must build participatory linkage or connection with the parents and the community stakeholders in general.

The existing capacity building activities of the school must give focus on community partnership and linkages that will highlight community building and networking among schools and other organizations in the private and public sectors that can support the work of schools (Gamage \& Zajda, 2009).

As shown in Table 2, both the student and teacher respondents perceived that all the instructional practices employed in Science subject were 'Observed' with an overall score of 2.93 to support curriculum and learning component of school-based management.

The results of the weighted mean indicate that indicator 1: Employ a variety of assessment strategies (e.g., multiple-choice test, essay tests, short answer test, fill in the blank test, matching test, demonstration to peers, portfolios, mastery checklist, student projects) (3.36) which was 'Observed' got the highest composite mean while indicator 10: Visit nearby schools for benchmarking of best teaching practices and strategic instructional materials (2.47) interpreted as 'Moderately Observed' got the lowest composite mean.

The findings reveal that when it comes to the instructional practices employed by Science teachers, they are good particularly in utilizing different assessment tools to gauge the academic performance of students. This justifies why majority of the students comprising of 79 students or 47 per cent in Science class has achieved 80 per cent to 84 per cent or "Satisfactory" academic performance. However, it reveals that these Science teachers have to take into account activities that will involve school-to-school partnerships in order to adopt best pedagogical practices and teaching materials that exist between and among schools. This is one contributory factor why there are 43 students or 26 per cent who have only attained 75 per cent to 79 per cent or "Fairly Satisfactory" academic performance. This finding is consistent with Wholstetter, Kirk, Robertson, and Mohrman 1997; Cheng Cheong, 1996 as cited by Al Kaabi (2015) who emphasized that in school-based management, schools provide the context necessary for learning while enabling 
participants to generate, implement, and become effective at applying pedagogical approaches to curriculum and instruction.

Table 2: Instructional Practices Observed in Science to Support Curriculum and Learning

Component

\begin{tabular}{cc}
\hline Indicators & \multicolumn{2}{c}{ Weighted } \\
& \multicolumn{2}{c}{ Mean } \\
& $x^{\text {VI }}$ \\
\hline
\end{tabular}

1 Employ a variety of assessment strategies (e.g., multiple-choice test, essay tests, short answer test, fill in the blank test, matching test, demonstration to peers, portfolios, mastery checklist, student projects).

2 Make comparative analysis with Mean Percentage Score results to monitor learning progress and make necessary improvements accordingly.

3 Monitor student responses and interactions during discussions.

$4 \quad$ Administer diagnostic test anchored on content and performance standards to identify strengths and weaknesses of students.

5 Discuss with parent/guardian issues other than student behaviour or academic performance.

$3.16 \quad \mathrm{O}$

$6 \quad$ Initiate immediacy of application of the teaching strategies/techniques learned from School Learning Action Cell (SLAC) session, In-Service Training, seminars, etc.

7 Inform (via text, call, email, or home visitation) parent/guardian as to the positive growth in student behaviour or academic performance.

8 Conduct remedial instruction and/or intervention programs for low performing students.

9 Vary the size and composition of learning groups during each lesson.

10

Visit nearby schools for benchmarking of best teaching practices and strategic instructional materials. 
Table 3 indicates that instructional practices observed in Mathematics subject support curriculum and learning component using school-based management system. The results reveal that all the indicators pertaining to the instructional practices perceived by both student and teacher respondents were 'Observed' with an overall mean of 3.11 .

The results of the weighted mean show that indicator 1: Monitor student responses and interactions during discussions obtained the highest score of 3.52 'Highly Observed' while indicators 9 and 10: Visit nearby schools for benchmarking of best teaching practices and strategic instructional materials (2.27) and Bring students outside the school and utilize community as an avenue for experiential learning (1.92) achieved the lowest composite mean which were both 'Moderately Observed.'

In terms of the instructional practices of Mathematics teachers, the findings show that they were wellversed in monitoring active participation of their students in their classes. This can be the reason why 54 students or 32 per cent have achieved 80 per cent to 84 per cent or "Satisfactory" academic performance.

However, like English teachers, they must consider learning opportunities that can be offered by and experienced in the community. Same with Science teachers, they also have to include initiatives to partner with other nearby schools so as to learn effective pedagogical techniques and teaching materials especially of the high performing schools in order to better the teaching and learning process (Wholstetter, Kirk, Robertson, and Mohrman 1997; Cheng Cheong, 1996) as cited by Al Kaabi (2015) and Brown (1990 cited in Dimmock, 2013).

Thus, lack of opportunities for authentic learning in the community and best teaching practices and strategic instructional materials patterned from other schools contributes why majority of the students which is 79 or 46 per cent in Mathematics class has only obtained 75 per cent to 79 per cent or "Fairly Satisfactory" academic performance. 
Table 3: Instructional Practices Observed in Mathematics to Support Curriculum and Learning Component

\begin{tabular}{|c|c|c|c|}
\hline & \multirow{2}{*}{ Indicators } & \multicolumn{2}{|c|}{$\begin{array}{l}\text { Weighted } \\
\text { Mean }\end{array}$} \\
\hline & & $\bar{X}$ & VI \\
\hline 1 & Monitor student responses and interactions during discussions. & 3.52 & $\mathrm{HO}$ \\
\hline 2 & $\begin{array}{c}\text { Re-teach lessons if necessary and provide enrichment activities that } \\
\text { further support learning; }\end{array}$ & 3.48 & $\mathrm{O}$ \\
\hline 3 & Impose and monitor classroom rules and regulations; & 3.45 & $\mathrm{O}$ \\
\hline 4 & $\begin{array}{l}\text { Discuss with parent/guardian a concern on their child's academic } \\
\text { performance and behaviour }\end{array}$ & 3.42 & $\mathrm{O}$ \\
\hline 5 & $\begin{array}{l}\text { Make comparative analysis with Mean Percentage Score results to } \\
\text { monitor learning progress and make necessary improvements } \\
\text { accordingly; }\end{array}$ & 3.41 & $\mathrm{O}$ \\
\hline 6 & $\begin{array}{l}\text { Give students an opportunity to assess their own work and progress } \\
\text { (e.g., using rubrics, checklist, or reflective journals); }\end{array}$ & 2.64 & $\mathrm{O}$ \\
\hline 7 & $\begin{array}{l}\text { Implement a learning activity that requires students to read and } \\
\text { write in the content area during each lesson; }\end{array}$ & 2.88 & $\mathrm{O}$ \\
\hline 8 & $\begin{array}{c}\text { Utilize other learning modalities (e.g., Alternative Delivery Mode } \\
\text { (ADM), Modular Approach) to accommodate students who are } \\
\text { under different conditions; }\end{array}$ & 2.50 & $\mathrm{O}$ \\
\hline 9 & $\begin{array}{c}\text { Visit nearby schools for benchmarking of best teaching practices } \\
\text { and strategic instructional materials }\end{array}$ & 2.27 & MO \\
\hline 10 & $\begin{array}{l}\text { Bring students outside the school and utilize community as an } \\
\text { avenue for experiential learning. }\end{array}$ & 1.92 & MO \\
\hline & OVERALL & 3.11 & $\mathrm{O}$ \\
\hline
\end{tabular}

Legend: $3.50-4.00$ (Highly Observed) $2.50-3.49$ (Observed) $1.50-2.49$ (Moderately Observed) $1.00-$ 1.49 (Not Observed)

Table 4 presents all indicators that describe how the school supports curriculum and learning implementation which serves as a validation of the instructional practices employed by teacher respondents in English, Science, and Mathematics subjects in Grade 10. As shown below, all the indicators are 'Observed' with an overall mean of 2.90 . 
However, indicators 9 and 10: Provides varied learning activities as well as individualized self-directed learning (2.00) and Has in place a functional assessment system, handled by a quality management team (2.00) were 'Moderately Observed.'

Lack of individualized and group-based activities for learning as well as the functional assessment system serves as contributory factor why 68 per cent of the students in English, Science, and Mathematics classes has only achieved 75 per cent to 79 per cent or "Fairly Satisfactory" academic performance.

These findings suggest that teachers should work on initiatives as to how they will get the students' maximum participation through the utilization of varied individual and group activities. This may be the effect of the insufficient instructional materials the school offers which is revealed in an interview with the teacher respondents.

On the other hand, although teachers employ varied assessment tools to gauge student performance, the school does not have quality management team which is responsible for the functional assessment system. 
Table 4: Descriptions on How the School Supports Curriculum and Learning

\begin{tabular}{|c|c|c|}
\hline \multirow[t]{2}{*}{ Indicators } & \multicolumn{2}{|c|}{$\begin{array}{l}\text { Weighted } \\
\text { Mean }\end{array}$} \\
\hline & $\bar{X}$ & VI \\
\hline
\end{tabular}

1 Provides curricular programs that address the students' individual differences and the development needs of the community.

$3.00 \quad \mathrm{O}$

Establishes articulation among curricular programs at all levels to improve integrative learning.

$3.00 \quad \mathrm{O}$

3 Designs flexible and responsive curriculum that adapts to local cultural conditions.

$3.00 \quad \mathrm{O}$

4

Initiates learning programs according to intended learner outcomes.

$3.00 \quad \mathrm{O}$

5

Uses a system that enables the students to assume personal

$3.00 \quad \mathrm{O}$ responsibility towards their own learning.

6

Maintains a secure, accurate, and functional student tracking

$3.00 \quad \mathrm{O}$

system (STS) based on the existing laws, policies, rules and regulations.

7

Apply innovative strategies that enable students to identify their learning strengths and weaknesses.

$3.00 \quad \mathrm{O}$

8 Demonstrates significant improvement in learning outcomes. $\quad 3.00 \quad \mathrm{O}$

$9 \quad$ Provides varied learning activities as well as individualized selfdirected learning.

$2.00 \quad \mathrm{MO}$

10 Has in place a functional assessment system handled by a quality $\quad 2.00 \quad$ MO management team.

OVERALL

$2.90 \quad \mathrm{O}$

Legend: $3.50-4.00$ (Highly Observed) $2.50-3.49$ (Observed) $1.50-2.49$ (Moderately Observed) 1.00 1.49 (Not Observed)

\section{Conclusion}

In the Philippines, SBM was cascaded in all public schools after the promising results revealed in three pilot projects of the Department of Education such as the Third Elementary Education Project (TEEP), 
Secondary Education Development and Improvement Project (SEDIP) and Basic Education Assistance for Mindanao (BEAM) aimed at supporting the SBM as an effective mechanism to improve the quality of education in the basic level.

As one of the public secondary schools in the Philippines committed to providing nothing but the best education services to the Filipino learners, the school has been upholding reforms of the Department of Education in order to live up to the department's mission and vision. To ensure that curriculum and learning standards are met, the school provides a plethora of learning opportunities that accommodate diverse learners. Each of the learning areas (English, Science, Mathematics, Filipino, Social Studies, Technical and Vocational Education, Music, Arts, Physical Education and Health, and Values Education) has developed and employed work plans intended to support curriculum and learning component.

However, despite different instructional practices employed by the faculty particularly in the three major subjects such as English, Science, and Mathematics, they must still work on programs and projects that will fortify their partnerships and linkages in the community and other public and private secondary schools in order to improve their pedagogical techniques and instructional materials. They must evaluate the quality of content of the learner's materials and make modules or supplementary materials if necessary. In addition to this, teachers must provide a plethora of interactive activities for self-directed and groupbased learning opportunities, utilize community for authentic or experiential learning; and strengthen functional assessment system.

Furthermore, the responsibility does not lie only on the educators. For the success of SBM system does not rest on the hands of these few actors. In this regard, the school leaders and managers must conduct remedial and intervention sessions to help low performing students improve their academic performance by mastering least-learned competencies. They must provide teachers teaching non-major subjects with intensive seminars and other capacity building activities for professional development. By seeking support from potential stakeholders and strengthen its relationship with them could lessen the loads associated with the outputs expected from SBM advocates. Together, these will all lead to the successful SBM implementation in a way of responding to the diverse needs of the students and teachers towards more effective and efficient curriculum and learning.

\section{References}

Abulencia, A. S. (2012). School-Based Management: A Structural Reform Intervention. The Normal Lights, 6(1).

Al Kaabi, A., \& Ali, S. (2015). An evaluation of the school-based management practices in the new school model: a study on al AIN schools.

Caldwell, B. (2004). School-Based Management. Education Policy Series, UNESCO International Academy of Education and International Institute for Educational Planning.

De Grauwe, A. (2004). "School Based Management (SBM): does it matter?" Paper commissioned for the EFA Global Monitoring Report 2005, The Quality Imperative. UNESCO, Paris.

DepEd Order No. 45, s. 2015. (2015). Guidelines on School-Based Management (SBM) Grants Retrieved 01 September 2019 from https://www.deped.gov.ph/2015/10/28/school-basedmanagement-grant/

Di Gropello, E. (2006). "A Comparative Analysis of School-Based Management in Central America." World Bank Working Paper No. 72, The World Bank, Washington, D.C.

Dimmock, C. (2013). School-based management and school effectiveness. Routledge. 
Galiani, S., \& Schargrodsky, E. (2002). Evaluating the impact of school decentralization on educational quality. Economia, 2(2), 275-314.

Gamage, D. T., \& Zajda, J. (2009). Decentralisation and school-based governance: A comparative study of self-governing school models. In Decentralisation, school-based management, and quality (pp. 3-22). Springer, Dordrecht.

Gertler, P., Patrinos, H., \& Rubio-Codina, M. (2006). Empowering parents to improve education: Evidence from rural Mexico. The World Bank.

Ling, C., Khattri, N., \& Jha, S. (2010). The effects of school-based management in the Philippines: An initial assessment using administrative data. The World Bank.

University of Missouri-Columbia. Middle Level Leadership Center (1986). School Improvement Surveys. Instructional Practices.

World Bank. (2007). What is School Based Management? An Introduction. Education Human Development Network. The World Bank, Washington D.C. 